\title{
Pemanfaatan Teknologi Dalam Pembelajaran Sebagai Upaya Peningkatan Kompetesnsi Pedagogik
}

\author{
Pebria Dheni Purnasari ${ }^{1}$, Yosua Damas Sadewo ${ }^{2}$ \\ ${ }^{1,2}$ Institut Shanti Bhuana, Bengkayang Kalimantan Barat \\ ${ }^{1}$ pebria.dheni@shantibhuana.ac.id \\ ${ }^{2}$ yosua.damas@shantibhuana.ac.id
}

\begin{abstract}
ABSTRAK
Proses pembelajaran yang efektif dan efisien membutuhkan strategi pembelajaran yang tepat. Seorang guru, harus mampu merancang dan melaksanakan pembelajaran yang baik sehingga mampu mencapai tujuan yang ditetapkan. Untuk dapat merancang dan melaksanakan pembelajaran dibutuhkan pemahaman terkait strategi mengajar serta penguasaan terhadap media ajar. Pembelajaran yang efektif terlihat dari bagaimana pembelajaran tersebut dapat menjawab kebutuhan siswa, serta tuntutan kemajuan jaman. Pelatihan pemanfaatan teknologi dalam mengajar menjadi hal yang tepat mengingat pendidikan di Indonesia harus dapat menyesuaikan dengan kemajuan teknologi, terlebih lagi di tengah situasi saat ini yang tidak memungkinkan untuk melakukan pembelajaran secara tatap muka langsung karena merebaknya virus Covid-19. Pemanfaatan teknologi dalam mengajar akan mendorong guru untuk menciptakan proses pembelajaran berbasis teknologi. Pelatihan ini dilakukan pada guru di SDN Wulungsari dengan fokus pemanfaatan teknologi dalam pembelajaran yang dilakukan secara daring. Melalui kegiatan pelatihan ini, ada peningkatan kemampuan pada para guru di SDN Wulungsari dalam hal pengelolaan pembelajaran berbasis teknologi di mana kemampuan tersebut berada pada kompetensi pedagogik.
\end{abstract}

Kata kunci: Strategi pembelajaran daring, media pembelajaran, teknologi pembelajaran, kompetensi pedagogik

\section{ABSTRACT}

An effective and efficient learning process requires appropriate learning strategies. A teacher, must be able to design and implement good learning so as to achieve the goals set. To be able to design and implement learning requires an understanding of teaching strategies and mastery of teaching media. Effective learning can be seen from how this learning can answer the needs of students, as well as the demands of the times. Training on the use of technology in teaching is the right thing considering that education in Indonesia must be able to adapt to technological advances, especially in the midst of the current situation where it is not possible to do face-to-face learning due to the spread of the Covid-19 virus. The use of technology in teaching will encourage teachers to create a technology-based learning process. This training was conducted for teachers at Wulungsari Public Elementary School with a focus on the use of technology in online learning. Through this training activity, there is an increase in the abilities of teachers at Wulungsari Public Elementary School in terms of managing technology-based learning where these abilities are in pedagogical competences.

Keywords: Online learning strategies, learning media, learning technology, pedagogical competences

\section{PENDAHULUAN}

Keberhasilan pembelajaran merupakan tujuan utama dalam proses pendidikan. Upaya yang dapat dilakukan dalam mencapai tujuan pendidikan adalah dengan mendesain proses pembelajaran yang tepat daya, tepat sasar, serta berdampak pada peningkatan kompetensi siswa baik dari aspek kognitif, afektif, dan psikomotorik. Untuk menunjang pelaksanaan pembelajaran terkhusus pada pendidikan di jenjang sekolah dasar, seorang guru harus mampu mendesain pembelajaran yang sesuai dengan kebutuhan siswa serta menyesuaikannya dengan perkembangan 
jaman. Pada tahun 2020, perkembangan pendidikan di Indonesia sudah tidak asing dengan pemanfaatan teknologi. Pembelajaran berbasis teknologi pada era sekarang ini bukan menjadi hal yang baru. (Setiawan, 2017) mengungkapkan bahwa perkembangan teknologi membawa dampak bagi dunia pendidikan yakni munculnya berbagai sumber belajar berbasis daring seperti perpustakaan daring, pembelajaran daring, bahkan diskusi yang saat ini dapat dilakukan secara daring dengan tujuan peningkatan kualitas pembelajaran. Merebaknya berbagai fitur ataupun platform yang menunjang pembelajaran merupakan peluang besar bagi dunia pendidikan untuk mencapai tujuan yang ditetapkan dengan mengkombinasikan strategi mengajar dengan memanfaatkan perkembangan teknologi. Untuk dapat mengembangkan strategi pembelajaran dengan memanfaatkan teknologi, membutuhkan tenaga pendidik yang berkompeten. Kompetensi pedagogik merupakan salah satu kompetensi yang harus dikuasai guru, mengingat kompetensi ini beruhubungan erat dengan apa yang menjadi tugas dan tanggung jawab seorang guru dalam mendesain pembelajaran.

(Afandi, et al., 2016) mengemukakan bahwa perkembangan teknologi yang semakin maju membawa perubahan bagi dunia pendidikan, perubahan ini bukan sekedar perubahan konten kurikulum, melainkan perubahan pedagogi yakni perubahan yang mendorong lahirnya pengajaran berbasis teknologi bukan sekedar pengajaran tradisional. Kondisi ini, mendorong guru untuk peka terhadap perkembangan jaman serta mampu mengembangkan dan meningkatkan kompetensinya termasuk kompetensi pedagogik. (Sumiarsi, 2015) mengartikan kompetensi pedagogik sebagai kemampuan yang dimiliki guru dalam mengelola pembelajaran. Lebih lanjut (Nur, 2014) mengartikan kompetensi pedagogik sebagai kompetensi yang membedakan profesi guru dengan profesi lainnya. Salah satu cakupan dalam kompetensi ini adalah penguasaan guru secara mutlak terhadap model, metode, strategi, dan teknik pembelajaran serta mampu menetapkannya dalam proses belajar mengajar. Guru yang memiliki kompetensi pedagogik dikatakan mampu merancang atau mendesain pembelajaran yang efektif dan efisien. Hal ini sebagaimana diungkapkan oleh (Purnasari \& Sadewo, 2019) bahwa guru perlu memikirkan pemilihan model pembelajarn yang tepat sehingga tercipta pembelajaran yang efektif, efisien, dan menarik. Dikatakan efektif jika desain pembelajaran tersebut memberikan dampak positif terhadap peningkatan hasil belajar siswa, serta mampu menyelesaikan permasalahan atau menjawab kebutuhan yang berkaitan dengan belajar mengajar. Selanjutnya pembelajaran yang efisien tergambarkan pada pelaksanaan pembelajaran diselesaikan sesuai dengan alokasi waktu yang direncanakan.

(Syamsuar \& Refliantor, 2018) mengungkapkan bahwa perkembangan pendidikan di Indonesia dalam memanfaatkan teknologi belum merata, hal ini disebabkan masih banyak wilayah di Indonesia yang tergolong sebagai wilayah terisolir. Kondisi tersebut menunjukkan adanya ketimpangan yang cukup besar antara daerah perkotaan dengan wilayah-wilayah pedalaman di Indonesia dalam hal penggunaan teknologi untuk menunjang proses pembelajaran. (Purnasari \& Sadewo, 2020) mengatakan bahwa kompetensi guru dalam merancang pembelajaran yang tepat dan sesuai kebutuhan diperlukan untuk mencapai tujuan yang ditetapkan, namun pada kenyataannya banyak guru yang belum memenuhi atau mencapai kompetensi pedagogik. Keterampilan guru dalam mengelola pembelajaran masih perlu terus ditingkatkan terkhusus dalam menguasai teknologi dan menggunakannya dalam pembelajaran.

Berdasarkan hasil observasi yang dilakukan pada SDN Wulungsari didapati sebagian besar guru kesulitan menggunakan teknologi untuk menunjang proses belajar mengajar karena pemahaman guru terkait teknologi pembelajaran masih terbatas. Banyak guru yang tidak memperbaharui dan meningkatkan ilmunya ketika menggeluti profesi guru. Padahal sudah seharusnya, guru harus selalu up to date dalam hal ilmu pengetahuan serta teknologi sehingga ada pembaharuan cara mengajar. Pada kenyataannya banyak guru yang masih mengikuti pola belajar yang sudah ketinggalan jaman. Oleh sebab itu diperlukan pembaharuan ilmu baik melalui kegiatan studi lanjut, workshop, seminar, bimbingan teknis, lokakarya, serta pelatihan-pelatihan lainnya yang menunjang dan mampu meningkatkan kompetensi guru terkhusus kompetensi pedagogik.

Pentingnya menguasai teknologi tidak lagi dapat dipandang sebelah mata, hingga tahun 2019 pola pembelajaran di sekolah tetap 
bisa dilakukan secara luring atau offline. Namun pada awal tahun 2020 dengan merebaknya wabah Covid-19, pemerintah mendorong beralihnya sistem serta strategi mengajar di mana guru dituntut untuk menguasai teknologi dan melakukan pembelajaran dengan berbasis teknologi. Hal ini dapat menjadi tantangan bagi guru sebagaimana diungkapkan oleh (Ridha, 2018) bahwa tantangan guru di era digital adalah memahami keunikan karakteristik dari siswa sebagai generasi digital. Guru harus mampu menyelaraskan tujuan pembelajaran dengan perkembangan siswa di era digital ini. Penerapan teknologi dalam pembelajaran juga tak bisa diabaikan begitu saja, mengingat siswa pada jaman ini merupakan generasi digital. Lebih lanjut (Ridha, 2018) menyatakan bahwa perkembangan TIK (Teknologi Informasi dan Komunikasi) sekarang ini dapat menjadi peluang besar yang dapat dimanfaatkan guru dalam meningkatkan relasi yang baik dengan wali murid, sehingga dapat terjadi keselarasan antara pendidikan di sekolah dan di rumah. (Wijayanti, 2011)mengungkapkan bahwa TIK dalam pembelajaran memiliki peran yakni membantu mengemas bahan ajar, hal ini dimaksudkan agar proses pembelajaran dapat berjalan lebih efektif. Hal senada juga diungkapkan oleh (Gunawan, 2016) bahwa TIK yang berperan sebagai sarana yang dapat digunakan guru dalam menyampaikan materi ajar. (Ridha, 2018) menjelaskan bahwa penggunaan teknologi dalam pembelajaran dapat diwujudkan dengan mengembangkan media pembelajaran berbasis elektronik, pemanfaatan media sosial dalam kegiatan belajar mengajar, dan mengembangkan strategi pembelajaran dari atau bahkan memadukan pembelajaran daring dan luring (blended learning).

Pada kenyataannya, sistem pembelajaran daring belum mampu diterapkan secara merata di Indonesia. Permasalahan serupa juga dialami oleh para guru di SDN Wulungsari di mana pembelajaran daring malah memicu banyak kendala dan menimbulkan permasalahan baru. Meskipun demikian, pembelajaran tetap diarahkan untuk daring sebagai bentuk upaya memutus rantai penyebaran virus Covid-19. Mengingat kebijakan yang dikeluarkan oleh Menteri Pendidikan dan Kebudayaan Republik Indonesia, di mana tidak dianjurkan untuk melakukan kegiatan belajar mengajar di sekolah (kemendikbud.go.id, 2020). Hal ini mendorong guru untuk membuka diri terhadap penggunaan teknologi dalam pembelajaran karena solusi dari pembelajaran daring adalah dengan menggunakan teknologi dalam kegiatan belajar mengajar.

Berbagai masalah tersebut pada akhirnya mendorong pihak sekolah untuk meningkatkan kompetensi pedagogik guru dengan mengadakan pelatihan, workshop, ataupun lokakarya guna membekali guru sehingga guru tetap dapat merancang dan melaksanaan pembelajaran dengan maksimal. SDN Wulungsari merupakan salah satu sekolah yang berupaya meningkatkan kompetensi pedagogik melalui pengadaan pelatihan terkhusus untuk guru sebagai tenaga pendidik dan pengajar di sekolah. Pemilihan lokasi pengabdian di dasarkan pada kebutuhan guru di SDN Wulungsari dan kesediaan para guru diberikan pelatihan dalam pemanfaatan teknologi dalam pembelajaran. SDN Wulungsari terletak di Kecamatan Selomerto Kabupaten Wonosobo, di mana lokasi dari SDN Wulungsari berada jauh dari pusat kota, namun tidak membuat para guru di SDN Wulungsari pasif, melainkan berupaya mengatasi permasalahan terkait pemanfaatan teknologi dalam pembelajaran dengan mengikuti pelatihan pemanfaatan teknologi dalam pembelajaran sebagai upaya peningkatan kompetensi pedagogik.

\section{METODE KEGIATAN Pelaksanaan kegiatan Program} Pengabdian Masyarakat (PPM) ini dilakukan dengan menggunakan metode ceramah, tutorial, dan diskusi yang dilakukan secara daring dengan media WhatsApp Group dan Zoom.us. Adapun tahapan pelaksanaan kegiatan PPM ini adalah sebagai berikut:

1) Tahap 1

Pada tahap 1, metode yang digunakan adalah ceramah dan diskusi. Peserta diberikan wawasan mengenai manfaat penggunaan media ajar yang dapat disiapkan secara daring. Selanjutnya dilakukan diskusi, di mana dibahas mengenai permasalahan utama dalam pengelolaan pembelajaran daring serta solusinya. Setelah disepakati solusi dari permasalahan sebagai bentuk kegiatan pelatihan pengelolaan pembelajaran dengan memanfaatkan teknologi maka ditentukan jadwal pelaksanaan untuk Tahap 2. Pertemuan pada Tahap 1 dilakukan 1 kali dengan durasi waktu 3 jam. 
2) Tahap 2

Tahap 2 dilaksanakan dengan menggunakan metode tutorial. Peserta pelatihan diberikan materi tentang merancang pembelajaran dengan memanfaatkan teknologi pembelajaran. Pada tahap ini juga dilakukan latihan langsung, sehingga peserta tidak hanya melihat namun melakukan praktik langsung sebagai bentuk umpan balik. Pertemuan pada Tahap 2 dilakukan sebanyak 8 kali dengan durasi waktu 3 jam pada setiap pertemuan.

3) Tahap 3

Pada Tahap 3 metode yang dilakukan adalah diskusi. Tahap ini dilakukan sebagai bentuk evaluasi bersama terkait kegiatan yang dilakukan. Pertemuan pada tahap 3 dilakukan 1 kali dengan durasi waktu 3 jam.

Kegiatan PPM ini dilakukan secara terjadwal dengan alokasi waktu 10 kali pertemuan dengan total jam pelaksanaan kegiatan PPM adalah 30 JPL.

\section{HASIL \& PEMBAHASAN}

Guru sebagai pendidik diwajibkan mampu merancang pembelajaran, melaksanaan pembelajaran dan melakukan evaluasi terhadap proses pembelajaran, di mana kemampuan tersebut tergolong dalam kompetensi pedagogik guru. Hal ini senada dengan yang diungkapkan (Suryana, 2013) bahwa kompetensi pedagogik meliputi "pemahanan tentang wawasan atau landasan kependidikan, pemahaman terhadap peserta didik, pengembangan kurikulum, silabus, perancangan pembelajaran, pelaksanaan pembelajaran yang mendidik dan dialogis, pemanfaatan teknologi pembelajaran, evaluasi proses dan hasil belajar, serta pengembangan peserta didik untuk mengaktualisasikan berbagai potensi yang dimilikinya". Memperhatikan pengertian tersebut, maka tugas seorang pendidik tidak sekedar mengajar saja melainkan mampu merancang proses pembelajaran dengan startegi yang tepat sesuai dengan kebutuhan dan perkembangan jaman. Sebagai bentuk langkah nyata dari hal tersebut, maka dilakukan kegiatan pelatihan sebagai bentuk Program

Pengabdian Kepada Masyarakat untuk menyiapkan guru yang mampu memanfaatkan teknologi terkhusus dalam pembelajaran terlebih lagi pada situasi yang saat ini tidak dianjurkan untuk melakukan pembelajaran tatap muka langsung mengingat merabaknya wabah Covid-19.

Kegiatan pelatihan pemanfataan teknologi dalam pembelajaran dilakukan selama 10 kali pertemuan dengan total jam pelaksanaan 30JPL, di mana pelaksanaannya dilakukan secara daring dengan menggunakan media Zoom dan WhatsApp Group. Sebagaimana disebutkan sebelumnya, kegiatan pelatihan ini dilakukan dalam 3 Tahap. Tahap pertama dilakukan pada tanggal 22 Juni 2020 dengan durasi selama 3 jam, di mana kegiatan ini meliputi:

1) Pemberian materi terkait strategi mengajar

2) Hal-hal yang perlu diperhatikan dalam merancang proses pembelajaran

3) Faktor-faktor yang mempengaruhi keberhasilan pelaksanaan pembelajaran

4) Diskusi dan tanya jawab terkait kendala dalam proses pembelajaran

5) Perencanaan solusi Setelah dilakukan pembahasan mengenai strategi mengajar, perencanaan pembelajaran, serta faktor-faktor yang mempengaruhi keberhasilan dalam pembelajaran, selanjutnya dilakukan kegiatan diskusi dan tanya jawab terkait materi yang telah dilakukan, kemudian diadakan pembahasan mengenai permasalahanpermasalahan serta kendala terkait pembelajaran sehingga dapat dirancang solusi sebagai bentuk tindak nyata penyelesaian permasalahan.

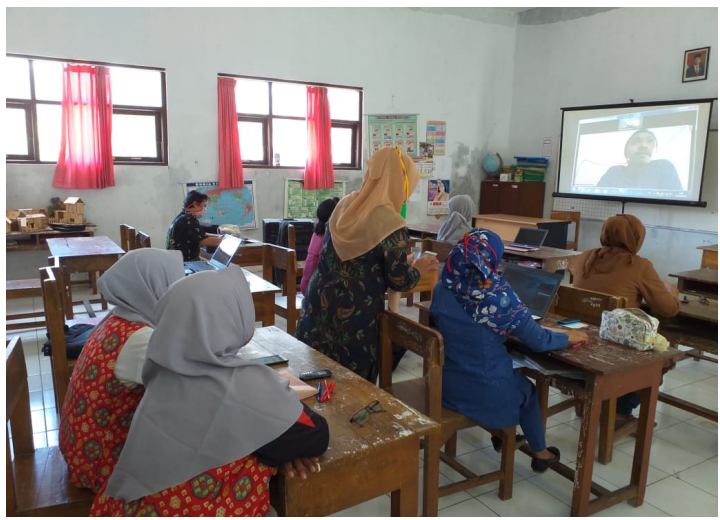

Gambar 1. Penjelasan Materi Strategi Pembelajaran

Berdasarkan hasil diskusi didapati beberapa permasalahan seputar proses pembelajaran diantaranya: pemilihan metode atau model pembelajaran, pemanfaatan teknologi dalam mengajar serta menyusun 
asesmen pembelajaran. Memperhatikan permasalahan tersebut, maka dilakukan diskusi lebih lanjut terkait solusi yang akan ditetapkan untuk menyelesaikan kendala yang dialami.

Dari hasil diskusi, maka disepakati bersama mengenai solusi permasalahan yang berfokus pada pemanfaatan teknologi pembelajaran.
Selanjutnya ditentukan jadwal kegiatan sebagai bentuk tindak lanjut dari solusi yang telah ditetapkan. Berikut jadwal kegiatan dari pelatihan pemanfaatan teknologi dalam proses pembelajaran.

Tabel 1 Jadwal Kegiatan Pelatihan SDN Wulungsari

\begin{tabular}{|c|c|}
\hline an & \\
\hline Senin, 22 Juni 2020 & $\begin{array}{l}\text { - Pemberian materi terkait strategi, perencanaan, serta faktor yang } \\
\text { mempengaruhi keberhasilan pembalajaran } \\
\text { - Tanya jawab terkait kendala dalam proses pembelajaran } \\
\text { - Perencanaan solusi }\end{array}$ \\
\hline Selasa, 23 Juni 2020 & $\begin{array}{l}\text { - Membuat e-mail melalui android } \\
\text { - Mengakses e-mail dari android } \\
\text { - Mengirim e-mail }\end{array}$ \\
\hline Rabu, 24 & $\begin{array}{l}\text { - Mengakses google form dari laptop } \\
\text { - Membuat soal/quiz pilihan ganda dengan google form }\end{array}$ \\
\hline Kamis, 25 Juni 2020 & $\begin{array}{l}\text { - Menyisipkan gambar pada google form } \\
\text { - Mengatur tampilan google form }\end{array}$ \\
\hline Jumat, 26 & $\begin{array}{l}\text { - Pelaporan progres pembuatan soal/quiz pilihan ganda dengan google } \\
\text { form }\end{array}$ \\
\hline Senin, 29 Juni 2020 & $\begin{array}{l}\text { - Memperpendek link soal dari google form dengan bitly } \\
\text { - Membagikan link melalui e-mail maupun WhatsApp }\end{array}$ \\
\hline Selasa & $\begin{array}{l}\text { - Mengakses google drive melalui e-mail yang telah dibuat } \\
\text { - Menyimpan file (word, pdf, ppt, excel, video, gambar) ke dalam } \\
\text { google drive }\end{array}$ \\
\hline Rabu, 1 Juli 2020 & $\begin{array}{l}\text { - Membuat kelas online dengan google class } \\
\text { - Memasukkan materi pembelajaran ke dalam google class } \\
\text { - Memasukkan tugas/quiz ke dalam google class } \\
\text { - Mengirimkan dan menyerahkan tugas yang telah dibuat ke google } \\
\text { class }\end{array}$ \\
\hline Kamis, 2 Juli 2020 & $\begin{array}{l}\text { - Memberikan penilaian dari tugas yang masuk } \\
\text { - Pelaporan progress }\end{array}$ \\
\hline Jumat, 3 Juli 2020 & - Evaluasi kegiatan \\
\hline $\begin{array}{l}\text { Setelah Tahap } 1 \text { selesai dilakukan, maka } \\
\text { dilanjutkan pada Tahap 2, di mana tahap ini } \\
\text { Tahap merupakan realisasi dari solusi yang } \\
\text { lirancang pada tahap sebelumnya. Kegiatan } \\
\text { pada Tahap } 2 \text { dilakukan dari tanggal } 23 \text { Juni } \\
2020 \text { sampai tanggal } 2 \text { Juli } 2020 \text { dengan total } \\
\text { am pelaksanaan 24JPL. Adapun kegiatan yang } \\
\text { dilakukan pada Tahap } 2 \text { berfokus pada } \\
\text { engelolaan pembelajaran secara daring, } \\
\text { nateri kegiatan pada Tahap } 2 \text { meliputi: }\end{array}$ & $\begin{array}{l}\text { terhadap pelaksanaan pembelajaran yang saat } \\
\text { ini dituntut dilakukan secara daring. Lebih } \\
\text { lanjut, ke lima materi tersebut merupakan hal } \\
\text { yang belum dikuasai guru di SDN Wulungsari, } \\
\text { sehingga pemberian pelatihan dapat } \\
\text { meningkatkan wawasan bagi guru terkait } \\
\text { strategi mengajar dan media mengajar berbasis } \\
\text { daring yang dapat dipilih untuk menunjang } \\
\text { proses pembelajaran. Capaian ini selajan } \\
\text { dengan pendapat yang dikemukakan oleh } \\
\text { (Sunanjar, 2016) bahwa penggunaan teknologi } \\
\text { dalam pembelajaran memiliki berbagai fungsi, } \\
\text { salah satunya adalah meningkatkan mutu } \\
\text { pembelajaran selain itu juga memudahkan guru } \\
\text { untuk menyampaikan materi ajar mengingat } \\
\text { kondisi saat ini pembelajaran diarahkan untuk } \\
\text { dilakukan secara daring. }\end{array}$ \\
\hline
\end{tabular}




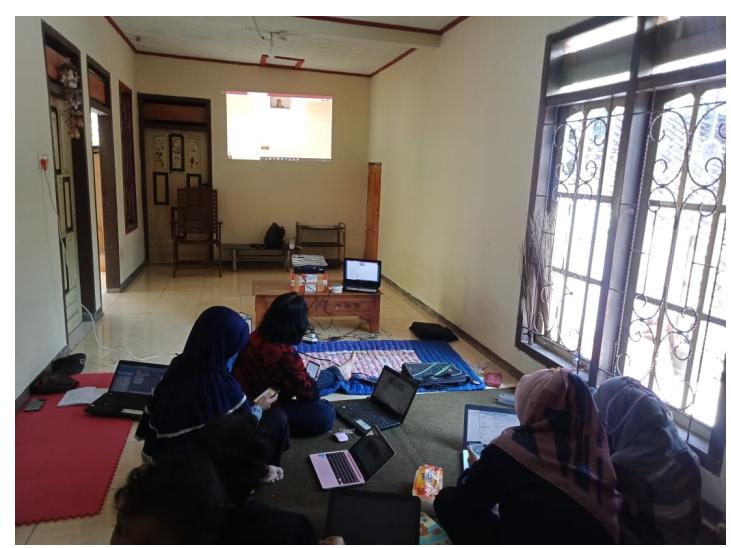

Gambar 2. Penjelasan Pemanfaatan Teknologi Pembelajaran

Kegiatan pada Tahap 2 dilaksanakan dengan metode tutorial yakni dengan dilakukannya praktik langsung dalam rangka mengimplementasikan materi yang telah diberikan. Pelaksanaan pelatihan pemanfaatan teknologi dalam pembelajaran dilakukan secara terjadwal dan dilanjutkan pada materi berikutnya setelah dipastikan para guru di SDN Wulungsari berhasil mempraktikan materi sesuai dengan arahan. Hal tersebut dilakukan karena indikator ketercapaian pelaksanaan pelatihan ini ditunjukkan dengan adanya peningkatan kompetensi guru terkhusus dalam strategi pembelajaran berbasis teknologi.

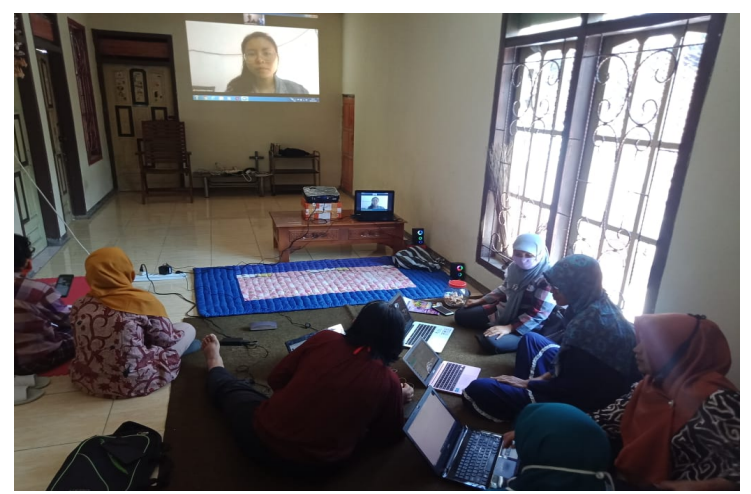

Gambar 3. Tutorial Pembuatan Media Pembelajaran Daring

Melalui Tahap 2, guru di SDN Wulungsari diarahkan untuk membuat akun $e$ mail, di mana e-mail tersebut digunakan sebagai langkah awal dalam menyiapkan media pembelajaran berbasis daring sebagai bentuk perencanaan strategi pembelajaran daring. Setelah pembuatan e-mail selesai dilakukan, selanjutnya para guru di SDN Wulungsari dikenalkan dengan berbagai platform yang dapat digunakan untuk menunjang pembelajaran daring sebagai bentuk pemanfaatan teknologin dalam pembelajaran. Kemudian, kegiatan pelatihan dilanjutkan dengan praktik membuat atau menyiapkan media pembelajaran dengan berbantuan media yang telah dijelaskan sebelumnya. Pada tahap ini juga diberikan penjelasan mengenai bagaimana cara penerapannya dalam proses belajar mengajar, sehingga ketercapaian kemampuan guru tidak sebatas berhasil menyiapkan media daring semata namun juga mampu mengimplementasikannya ke dalam proses pembelajaran.
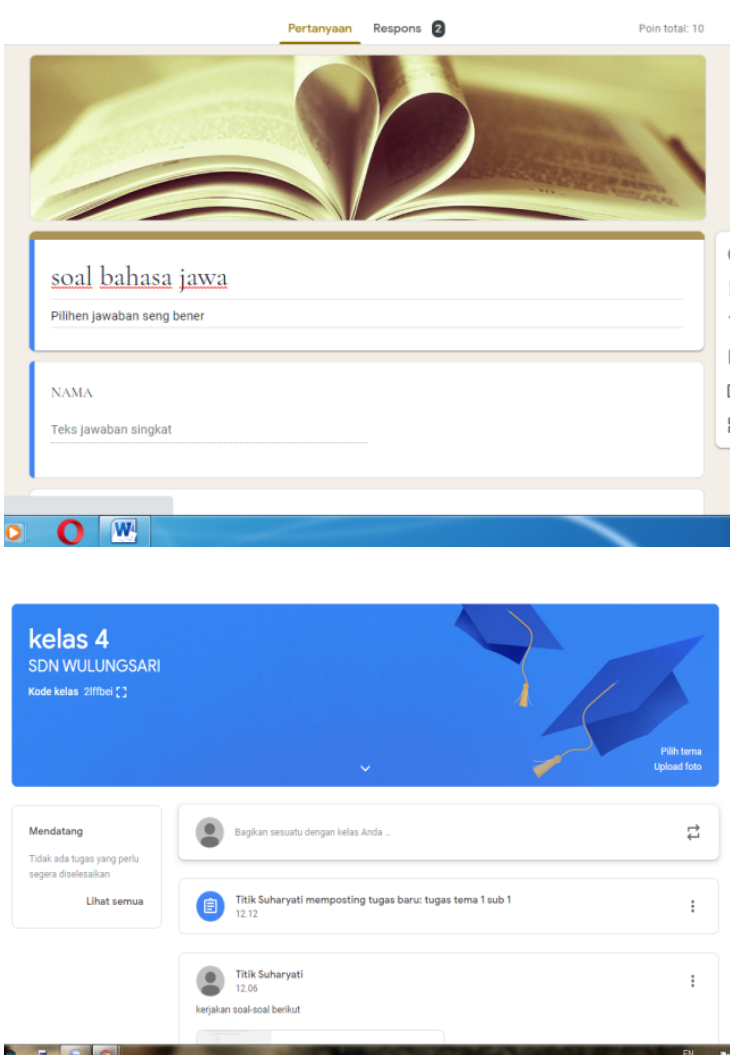

Gambar 4. Hasil Praktik Pemanfaatan Berbagai Media Untuk Kepentingan Pembelajaran

Tahap 3 merupakan tahap terakhir dalam pelatihan pemanfaatan teknologi dalam pembelajaran. Tahap ini dilakukan pada tanggal 3 Juli 2020 dengan durasi waktu selama 3 jam. Adapun kegiatan yang dilakukan pada tahap ini adalah kegiatan evaluasi. Setiap guru diberikan waktu untuk mempresentasikan hasil praktik yang telah dilakukan, selain itu juga diberikan kesempatan bagi para guru untuk mendiskusikan permasalahan yang dihadapi ketika menggunakan media pembelajaran berbasis daring. Pada tahap ini juga dilakukan pengukuran terkait tingkat 
kepuasan guru terhadap pelatihan yang telah dilakukan, serta kemampuan guru dalam mengelola pembelajaran secara daring. Berdasarkan hasil evaluasi, diketahui bahwa tingkat kepuasan guru terhadap pelatihan yang diberikan berada pada kategori 92.5\%. Pelatihan pemanfaatan teknologi dalam pembelajaran menjadi solusi yang tepat di tengah kondisi yang tidak menungkinkan dilakukannya pembelajaran secara tatap muka langsung. Selain itu, kegiatan pelatihan ini menambah wawasan bagi para guru dalam merancang strategi pembelajaran berbasis teknologi sehingga pembelajaran tetap dapat berlangsung. Kemampuan guru di SDN Wulungsari dalam memanfaatkan teknologi juga mengalami peningkatan setelah mengikuti perlatihan ini. Meningkatnya wawasan guru pada strategi pembelajaran, pemilihan media ajar dengan memanfatkan kemajuan teknologi serta dapat mengimplementasikannya dalam pembelajaran sehingga tercipta pembelajaran berbasis teknologi menunjukkan bahwa guru telah mengalami peningkatan salah satu kompetensi yakni kompetensi pedagogik.

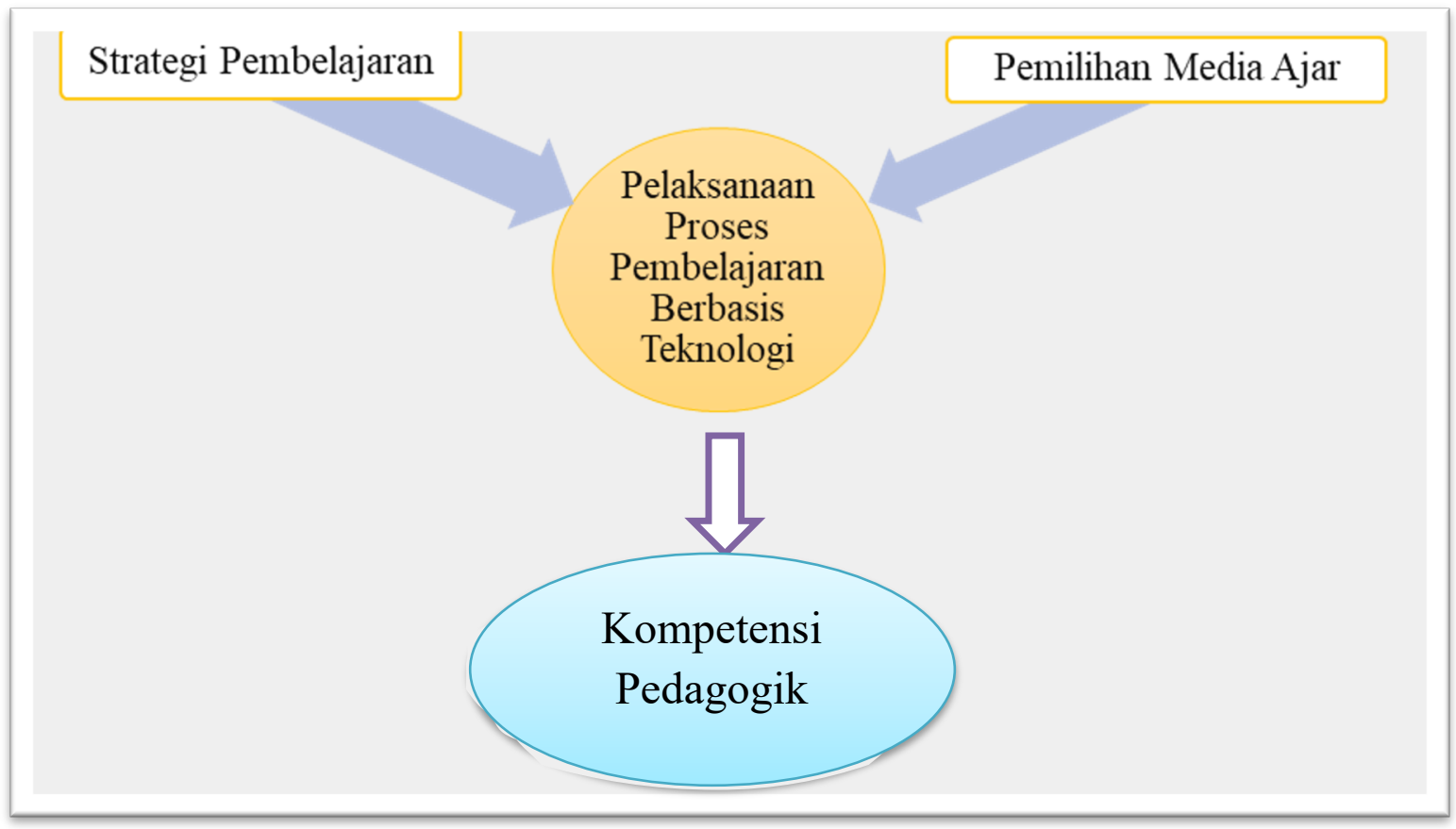

Gambar 5. Alur Kegiatan Pembelajaran Berbasis Teknologi

Hasil evaluasi tersebut menunjukkan keberhasilan pelatihan pembelajaran daring yang telah dilakukan bagi para guru di SDN Wulungsari. Peningkatan kemampuan guru secara jelas terlihat pada pemahaman akan media daring dan bagaimana memanfaatkan teknologi dalam pembelajaran. Hal ini terlihat jika sebelumnya pemanfaatan teknologi dalam mengajar hanya sebatas dengan penggunaan powerpoint namun melalui pelatihan yang telah dilakukan, para guru di SDN Wulungsari tidak sekedar mengenal berbagai platform melainkan mampu menggunakannya untuk menunjang proses belajar mengajar. Melalui pelatihan ini, ada peningkatan yang terhadap wawasan guru serta implementasi teknologi dalam pembelajaran. Di mana kemampuan tersebut tergolong dalam kompetensi pedagogik. Hal ini sebagaimana diungkapkan oleh (Purnasari \& Sadewo, 2020) bahwa kompetensi pedagogik guru terlihat pada kemampuan guru dalam menguasai strategi ajar, media ajar, metode ataun model dan dapat mengimplementasikannya dalam proses pembelajaran sehingga mendukung tercapainya pembelajaran yang efektif dan efisien. Dengan demikian, keberhasilan pelaksanaan penelitian ini mengidikasikan bahwa ada peningkatan kompetensi pedagogik guru di SDN Wulungsari yang diantaranya tergambarkan pada kemampuan pengelolaan pembelajaran di mana pembelajaran tersebut didesain dengan memanfaatkan kemajuan teknologi. (Wijayanti, 2011) mengungkapkan bahwa pemanfaatan teknologi dalam pembelajaran sangat membantu guru dalam pengelolaan pembelajaran serta hal-hal lainnya yang berhubungan dengan kegiatan belajar mengajar. Pelatihan ini sekaligus menambah wawasan pada para guru di SDN Wulungsari 
terkait teknologi yang semakin maju dapat dimanfaatkan untuk menunjang pembelajaran sehingga dapat menciptakan pembelajaran

\section{KESIMPULAN \& SARAN}

Pelatihan pemanfaatan teknologi untuk menunjang proses pembelajaran yang telah dilakukan memberikan dampak positif terhadap meningkatnya kompetensi pedagogik guru di SDN Wulungsari terkhusus pada kemampuan perencanaan strategi mengajar secara daring serta pemilihan media daring yang sesuai dengan kebutuhan. Peningkatan kemampuan tersebut menjadi wujud nyata bagi guru dalam memperbaharui ilmu pengetahuannya serta upaya dalam meningkatkan kualitas pendidikan. Pelatihan pemanfaatan teknologi dalam pembelajaran mendorong para guru di SDN Wulungsari untuk mendesain dan mengimplementasikan proses pembelajaran berbasis teknologi. Keberhasilan pelatihan ini sekaligus menunjukkan adanya peningkatan kompetensi guru khususnya kompetensi pedagogik.

Saran yang dapat diberikan bagi para guru di SDN Wulungsari adalah untuk tetap berkomitmen dalam meningkatkan kompetensinya tidak hanya kompetensi pedagogik melainkan juga kompetensi lainnya yang harus dimiliki oleh seorang guru. Bagi para guru lainnya, untuk selalu memperbaharui ilmu yang dimiliki, sehingga dapat merancang dan menciptakan pembelajaran unggul, efektif dan efisien.

\section{DAFTAR PUSTAKA}

Afandi, Junanto, T. \& Afriani, R., 2016. Implementasi Digital-Age Literacy Dalam Pendidikan Abad 21 di Indonesia. Surakarta, Universitas Negeri Surakarta, pp. 113-119.

Gunawan, A., 2016. Pemanfaatan Teknologi Informasi dan Komunikasi Melalui Penggunaan Media Pendidikan Dalam Pembelajaran IPS SD. Jurnal Penelitian Pendidikan, 3(2), pp. 16-24.

kemendikbud.go.id, 2020. SE Mendikbud: Pelaksanaan Kebijakan Pendidikan Dalam Masa Darurat Penyebaran Covid-19, Jakarta: kemendikbud.go.id.

Nur, A. A., 2014. Meningkatkan Kompetensi Pedagogik Guru di SD Yayasan Mutiara Gambut. Jurnal Bahana Manajemen Pendidikan, pp. 65-831. yang unggul dengan memperhatikan perkembangan dan kemajuan jaman.

Purnasari, P. D. \& Sadewo, Y. D., 2019. Penerapan Model Pembelajaran PBL Dalam Meningkatkan Aktivitas, Minat, dan Hasil Belajar Ekonomi Pada Siswa Kelas X (Studi Kasus Pada SMA Negeri 1 Bengkayang). Sebatik, 23(2), pp. 489497.

Purnasari, P. D. \& Sadewo, Y. D., 2020. Perbaikan Kualitas Pembelajaran Melalui Pelatihan Pemilihan Model Pembelajaran dan Pemanfaatan Media Ajar di Sekolah Dasar Wilayah Perbatasan. Jurnal Publikasi Pendidikan, 10(2), pp. 125-132.

Ridha, M., 2018. Menjadi Guru di Era Digital. [Online]

Available at: https://geotimes.co.id/opini/menjadiguru-di-era-digital-2/ [Accessed 202002 24].

Sadewo, Y. D. \& Purnasari, P. D., 2019. Peningkatan Hasil Belajar dan Self Eficacy Siswa Melalui Model Pembelajaran Carousel Feedback dan Showdown Pada Mata Pelajaran Kewirausahaan. Jurnal Sebatik, 23(2), pp. 522-527.

Setiawan, W., 2017. Era Digital dan Tantangannya. Sukabumi, Universitas Muhammadiyah, pp. 1-9.

Sumiarsi, N., 2015. Analisis Kompetensi Pedagogik dan Pengembangan Pembelajaran SD Negeri 041 Tarakan. Jurnal Kebijakan dan Pengembangan Pendidikan, 3(1), pp. 99-104.

Sunanjar, F., 2016. Pemanfaatan TIK untuk Pembelajaran, Jakarta: Kompasiana.

Syamsuar \& Refliantor, 2018. Pendidikan dan Tantangan Pembelajaran Berbasis Teknologi Informasi di Era Revolusi Industri 4.0. E-Tech, 6(2), pp. 1-13.

Wijayanti, I. D., 2011. Peningkatan Pendidikan Berbasis ICT. Yogyakarta: UIN Sunan Kalijaga. 